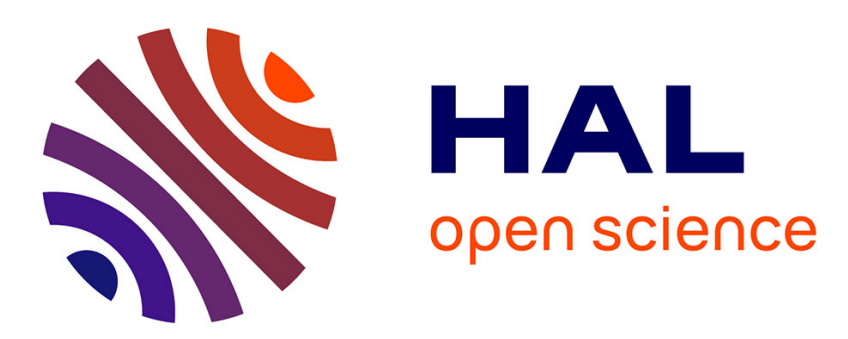

\title{
Management Innovation and Open Innovation: For and Towards Dialogue
}

\author{
Cécile Ayerbe, Sandra Dubouloz, Sophie Mignon, Marc Robert
}

\section{To cite this version:}

Cécile Ayerbe, Sandra Dubouloz, Sophie Mignon, Marc Robert. Management Innovation and Open Innovation: For and Towards Dialogue. Journal of Innovation Economics \& Management, 2020, Managerial Innovation and Open Innovation Strategies, 32, pp.13-41. 10.3917/jie.032.0013 . hal02985953

\section{HAL Id: hal-02985953 \\ https://hal.science/hal-02985953}

Submitted on 26 Nov 2020

HAL is a multi-disciplinary open access archive for the deposit and dissemination of scientific research documents, whether they are published or not. The documents may come from teaching and research institutions in France or abroad, or from public or private research centers.
L'archive ouverte pluridisciplinaire HAL, est destinée au dépôt et à la diffusion de documents scientifiques de niveau recherche, publiés ou non, émanant des établissements d'enseignement et de recherche français ou étrangers, des laboratoires publics ou privés. 


\section{MANAGEMENT INNOVATION AND OPEN INNOVATION: FOR AND TOWARDS DIALOGUE ${ }^{1}$}

\section{Cécile AYERBE}

cecile.ayerbe@univ-cotedazur.fr

Université Côte d'Azur, Groupe de Recherche en Droit, Economie et Gestion,

\section{Sandra DUBOULOZ}

sandra.dubouloz@univ-smb.fr

Université Savoie Mont Blanc, Institut de REcherche en Gestion et Economie,

\section{Sophie MIGNON}

Université de Montpellier, Montpellier Recherche en Management

sophie.mignon@umontpellier.fr

\section{Marc ROBERT}

Montpellier Business School, Montpellier Recherche en Management, m.robert@Montpellier-BS.com

${ }^{1}$ We would like to thank Joel West for his remarks which have allowed us to significantly improve this manuscript. 


\section{INTRODUCTION}

The literature on innovation is characterized by a wide variety of studies, but they have a marked "technological" bias illustrated by the much larger number of publications concerning technological innovation (TI) than articles on management innovation (MI) (Pitsis et al. 2012). MI, also called organizational, administrative, or managerial innovation has been conceptualized in contrast to technology-based product and process innovations and includes new organizational structures, administrative systems, and management practices (Birkinshaw et al, 2008, Damanpour, 2014).

The literature on innovation is currently mainly techno-centric.

Such is the case of the open innovation (OI) paradigm that has been mobilized to identify the antecedents, obstacles or even effects of product innovations (Gassman et al, 2010). More precisely, through the OI paradigm the research on TI has highlighted the importance of organizations being open to actors outside their boundaries (Chesbrough, 2003; Chesbrough, 2006; Dahlander, Gann, 2010; Chesbrough, Bogers, 2014; West et al., 2014; Aloini et al., 2017; Bogers et al., 2018); However, OI paradigm has thus not been clearly mobilized in its own right in the research on MI, as if it were only relevant to TI. A very recent analysis of the field of MI by Khosravi et al. (2019) supports this view indicating that the literature on MI rarely covers questions specifically concerning OI.

However, in the case of MI, few research have underlined the importance of external agents of change and/or external sources of knowledge (Birkinshaw et al., 2008; Mol, Birkinshaw, 2009, 2014; Huang, Rice, 2012; Damanpour et al., 2018).

Furthermore, through its most recent studies, the OI literature clearly calls for more research involving an "organizational" level of analysis explicitly referring to the organizational designs and practices that underlie openness (Bogers et al., 2018). The authors concerned consider that research regarding 'formal and informal organisational structures and managerial tools that support different forms of openness' (2018, p. 23) is still in its infancy. Aloini et al. $(2017,1086)$ find it regrettable that 'too little attention continues to be dedicated to the set of tools firms can use to support the implementation of OI'. More generally, knowledge is lacking on 'how to organise for OI?' (West, Bogers, 2014). Evidently, then, the OI literature offers a research field that explicitly integrates the organizational and managerial dimensions of openness, taking the related structures, instruments and practices into consideration. Yet the question still seems to be emerging, and little room appears to be left to consider it in relation to non-technological innovations.

This article proposes to bridge the gap between the two literatures and set up a dialogue between them, to mutually cover some of their neglected areas. For OI, those areas relate to organization and management, and the question of 'how to organize and manage OI?' For MI, they concern further exploration of the contributions of external actors and sources of knowledge to the emergence, adoption and diffusion of MI. The objective of this article is thus to show that initiating a dialogue between these two fields can be a source of complementary emerging themes in OI research to those identified by West et al (2014) or Gassmann et al (2010) and a mean to advance our understanding of the drivers, moderators, mediators and outcomes of MI (Khosravi et al. (2019).

To start up this dialogue, we devote the first section of this paper to a presentation of the two fields and their implicit links. The second section seeks a clearer description of the results 
from MI research that make use of the OI paradigm (explicitly or otherwise), or conversely the findings at the organizational level of OI (i.e. the associated managerial practices and organizational designs) which echo the literature on MI. The limitations of this paper lead to suggestions, in the final section, of research avenues that would benefit from crossfertilization between the two fields and should be mutually enriching.

\title{
TWO PARTIALLY OVERLAPPING LITERATURES IN THE FIELD OF INNOVATION MANAGEMENT
}

\author{
Open Innovation: a prolific field of research, still largely confined to management of \\ technological innovation
}

\section{Definitions}

In his 2003 book "Open Innovation: The New Imperative for Creating and Profiting from Technology", and then in 2006 in "Open Business Models", Henry Chesbrough introduced what he calls a new paradigm in innovation management: OI. The scope of this paradigm is reflected in a very large number of articles and special issues: Innovations-Revue d'Economie et Management de l'Innovation/Journal of Innovation Economics and Management (2012, 2016, 2018), R\&D Management (2006, 2009, 2010, 2019, 2020), Industry and Innovation (2008), International Journal of Technology Management (2010), European Journal of Innovation Management (2010), Technovation (2011), Research Technology Management (2012), Revue Française de Gestion (2011), International Small Business Journal (2013), Research Policy (2014) and more recently, a special section on OI in the California Management Review (2018).

Among the many definitions used, Chesbrough's in his pioneering book remains one of the most frequently quoted: 'open innovation is a paradigm that assumes that firms can and should use external ideas as well as internal ideas, and internal and external paths to market, as firms look to advance their technology' (Chesbrough, 2003, p. 24). In a similar style, in 2006 he defined OI as '... the use of purposive inflows and outflows of knowledge to accelerate internal innovation, and expand the markets for external use of innovation, respectively' (Chesbrough, 2006, p. 1). Countering the "closed" innovation model, the central idea of OI is that in an environment of intensifying internationalization and technological complexity, a single organization cannot innovate alone (Dahlander, Gann, 2010). Internal R\&D centres should therefore no longer be considered as the only suppliers of innovation. On the contrary, inter-organizational relationships can be a way to obtain knowledge to accelerate R\&D processes, and turn the technologies developed to profitable uses. The pooling of knowledge is central for openness as the firm's boundaries become porous. This lies in its very essence, as he reasserted in 2014, defining OI as 'a distributed innovation process based on purposively managed knowledge flows across organizational boundaries' (Chesbrough, Bogers, 2014). This idea of flows, both incoming and outgoing, is essential to the defence of the concept. But in addition to this two-way circulation of knowledge, Chesbrough and Bogers argue that "what was unspecified and unmanageable before can now be specified and managed in the open innovation model". This "manageable", "systematic" or "intentional" dimension of innovation, backed up by business cases, differentiates OI from spillover effects (Chesbrough, Bogers, 2014) and has undeniably contributed to its originality and rise. OI also 
gives new status to intellectual property rights (IPR), which, far from acting as an instrument for defending established positions, are instead seen as vectors for openness that help the firm identify partners and build secure relationships (Cohendet, Pénin, 2011). Chesbrough thus clearly indicates that pooling knowledge requires proactive management of IPR (Ayerbe, 2016). This liberates the firm from the traditional NIH (Not Invented Here) syndrome ${ }^{2}$ by integrating technologies developed by external R\&D units that contribute to value creation. Pooling knowledge is also a remedy for a new syndrome denounced by Chesbrough: NSH (Not Sold Here) syndrome, seen when holders of IPR refuse to license their inventions to third parties.

Openness thus fosters creation and capture of value through open Business Models: 'Open models create value by leveraging many more ideas, due to their inclusion of a variety of external concepts. Open models can also enable greater value capture by using a key asset, resource, or position, not only in the company's own business but also in other companies' businesses' (Chesbrough 2006, p. 2). Such business models have often been confused with the very concept of OI, both in academic work and by practitioners (Vanhaverbeke, Chesbrough, 2014), even though these authors stress the difference, highlighting the importance of value creation and value capture mechanisms which go beyond product innovation to give the firm a competitive advantage. As technology has no intrinsic value, only establishment of a Business Model will enable the firm to draw value from it (Ayerbe, Chanal, 2011).

\section{Recognized processes of openness}

Three now well-known processes describe the possibilities of openness (Gassmann \& Enkel, 2004; Enkel et al., 2009): the inside-out process (or outbound process), the outside-in process (or inbound process) and the coupled process, and they are not mutually exclusive (Aloini et al., 2017). Based on a literature review covering 150 articles published in the best journals, Dahlander and Gann (2010) enrich this typology by introducing a distinction between pecuniary and non-pecuniary dimensions of openness.

The outside-in process, being closely associated with openness in the exploration of new knowledge, is the most frequently studied (Mortara, Minshall, 2011, Penin et al., 2011; Bogers et al. 2018). This must of course be considered in the light of the extensive research on absorption capacities deriving from the work of Cohen and Levinthal (1990). The outsidein process aims to enhance the corporate knowledge base, and is founded on integration of technologies from a variety of partners: suppliers, competitors, research centres (Aloini et al., 2017). In line with the distinction defined by Dahlander and Gann (2010), it results from transactional mechanisms via "acquiring" logics, or non-transactional mechanisms in "sourcing" logics. More specifically, acquiring involves "spinning in", or "licensing-in" which presumes transfers of IPR. Sourcing consists of building connections with partners such as suppliers, customers, and research centres in order to make improvements to in-house developments.

The inside-out process has received the least attention in both academic studies and business practice (Bogers et al., 2018), and yet it is the truly innovative face of the OI model (Cohendet, Pénin, 2011). It describes how the firm introduces and commercializes its ideas on the market, in two ways: selling, or revealing (Dahlander, Gann 2010). Selling is purely transactional and gives rise to licensing-out and spin-off practices that are all sources of income. Revealing, meanwhile, displays knowledge without expecting an immediate income from it: standard-setting is one example of this (Henkel et al. 2014).

The coupled process consists of pooling knowledge and co-creation (Enkel et al., 2009). It is founded on a combination of the two previous processes: the 'coupled type of open innovation

${ }^{2}$ Antons and Piller (2015) 
involves combining purposive inflows and outflows of knowledge to collaboratively develop and /or commercialize an innovation' (Chesbrough, Bogers, 2014). It gives rise to codevelopments, joint projects, alliances, consortiums and R\&D cooperations.

\section{Consideration of organizational practices and structures in the OI research}

As noted earlier, OI has given rise to a rich body of literature which has paid considerable attention to organizational practices and structures, making it possible to consider them in relation to MI. Several authors have published summaries of the field, proposing a structure and areas for investigation (Bogers, Chesbrough, 2014; Dahlander, Gann, 2010; Huizingh, 2010; West, Bogers, 2014; West et al, 2014). It is evident that these summaries agree on the importance of the phenomenon, while pointing out that it is confined to management of TI and has not spread widely to management in general, or even to related disciplines such as economics (West et al., 2014). Randhawa et al. (2016, p. 755) underline that in the end, 'OI research is a rather closed affair'. A presentation of this research can be drawn up by reference to its research themes, and levels of analysis.

Regarding the research themes, following on from Chesbrough's pioneering work, OI research has largely been conducted in large Western groups in technology-intensive industries (electronics, biotechnologies, automobile), with a clear focus on TI. Gassman (2006) reports that OI has been extensively studied in settings of globalization and technological intensity that are conducive to new Business Models. When it relates to the processes identified earlier, this research is broadly dedicated to outside-in processes involving seeking out and acquiring external technologies, identifying partners, and developing links with certain key partners such as universities. Some of this research, however, looks at external commercialization logics, notably via licensing practices. More recent research has extended to new areas and settings (Vanderverke, Chesbrough, 2014; Bogers et al., 2018), including low-tech services and sectors, small and medium-sized businesses, emerging countries, and the public sector or more generally non-profit organisations. Bogers et al. (2018) stress the importance of this broader approach, in which OI is seen as playing a key role in development of economies, particularly due to the importance of digital disruption. They introduce the idea of the "Three Opens": Open Innovation, Open Science and Open to the World.

Regarding the levels of analysis, several authors review the literature on that basis: West et al. (2006), Randhawa et al. (2016) and Bogers et al. (2018), this last article going into the most depth. West et al. (2006) identify five levels: individuals and groups, the firm, interorganizational value networks, the industry or sector, and national institutions and innovation systems. Randhawa et al. (2016) list three levels: firm-centric, management of OI networks and the role of users and communities. At the firm-centric level, research has largely been devoted to management of knowledge and technologies, and R\&D under a 'firm-driven approach' that gives rise to many investigations of absorption/combination capacities, or exploration/exploitation capacities. Network-driven approaches, which are rarer, focus on the different types of partnerships, the role of IPR, and the influence of the setting on network structures. The role of users and communities has been particularly studied in dedicated sectors such as open source softwares, or mechanisms such as crowdsourcing. In a similar vein, Bogers et al. (2018) distinguish five levels of analysis in detail: intra-organizational, organizational, extra-organizational, inter-organizational and the general level of industry, regional innovation systems and society). The organizational level explicitly refers to the designs and practices underlying OI ('organisational design, practices and processes for integrating external sources of innovation', cf table 2). Bogers et al. note that the research is 
still emerging on 'formal and informal organisational structures and managerial tools that support different forms of openness' (2018, p.23). They call for more research on the organizational modalities of openness, unambiguously observing that how to organise for OI is not yet fully understood - West, Bogers (2014) - which calls for additional research on structures, mechanisms and tools for OI' (2018, p. 30). Huizingh (2010), too, observes that understanding openness requires the study of "OI practices" related to the still largely underexplored 'how to do it' question. More recently, on the same question, Aloini et al. (2017, p. 1086) also note with regret that 'too little attention continues to be dedicated to the set of tools firms can use to support the implementation of OI'.

As this shows, the literature on OI offers a vast field of research that explicitly integrates the organizational and managerial dimension of openness, taking into consideration structures, instruments and practices at different levels of analysis. However, as the question is apparently still emerging, there is little room for considering it in connection with nontechnological innovations.

A similar analysis of research in the field of MI also shows that the MI literature pays little attention to OI issues.

\section{MI: a fast-growing field of research, still largely confined to the intra-organizational level of analysis}

\section{Definitions}

A variety of overlapping terms is in use in the literature to represent MI. Kimberly (1981) was one of the first authors to work on MI and used the term Managerial innovation, defining it as 'what managers are and do'. He saw managers primarily as 'decision-makers' and MI as 'a means of changing the processes of decision-making'. He defined MI as 'any program, product or technique which represents a significant departure from the state of the art of management at the time it first appears and which affects the nature, location, quality, or quantity of information that is available in the decision-making process' (Kimberly, 1981, p. 86). Damanpour and Evan (1984) spoke about "administrative innovations" defined as those that occur in the social system of an organization, which refers to the relationships among people interacting to accomplish a specific goal. They included new rules, roles, procedures and structures. Alänge et al. (1998) and Edquist et al. (2001) used the term of "organizational innovation" for innovations in management practices, administrative processes, formal organizational structure and about organization of business activities and human resources. As the term of "organizational innovation" had sometimes been used to imply any type of innovation generated or adopted by organizations, including new products (Damanpour, 1991), Birkinshaw et al. (2008) have chosen the term "MI" and proposed one definition, which became the established standard, although some nuance has since been added. That definition was the following one: 'the generation and implementation of a management practice, process, structure, or technique that is new to the state of the art and is intended to further organizational goals' (Birkinshaw et al., 2008, p.829). Like Hamel (2006), academic authors stress the disruptive dimension of MI. Hamel defined MI as a ' marked departure from traditional management principles, processes, and practices or a departure from customary organisational forms that significantly alters the way the work of management is performed. Put simply, Management Innovation changes how managers do what they do' (Hamel, 2006, p. 71). This body of research thus emphasises the importance of MI's radical aspect. Later, the same authors accepted a softening of MI's radical nature as presented in these initial definitions ('new to the state of the art'), bringing it to a more 
relative level ('new to the firm') (Mol, Birkinshaw, 2009). Note that Damanpour was quick to accept that the key feature of novelty in $\mathrm{MI}$ is relative, with most research considering that it only needs to be new for the firm (Damanpour et al. 2009). Damanpour and Aravind defined MI as 'new organizational structures, administrative systems, management practices, processes, and techniques that could create value for the organization' (Damanpour, Aravind, 2012, p.424). As non-technological innovation of processes, MI is called 'systemic' since it has an impact on the overall process of transforming inputs into outputs, and cannot be implemented independently of the organization's systems (Gopalakrishnan et al., 1999). Damanpour (2014) considers the term MI an umbrella concept that encompasses both administrative innovations and organizational innovations. In the opinion of Hamel and Breen (2008), MI primarily relates to anything that substantially modifies the way management is exercised.

Since its definition stabilized, interest has revived in the MI concept in the last decade (Volberda et al., 2014; Mignon et al., 2017; Robert et al., 2017; Khallouk, Robert, 2018; Khosravi et al., 2019; Giuliani et al., 2018; Robert et al., 2019). In the final analysis, it is essential to remember that MI always significantly modifies the way managers execute their management tasks in pursuit of a performance goal. Does this mean that any change in a manager's professional practices constitutes a management innovation? Clearly, the answer is no, as Hamel writes: 'While operational innovation focuses on a company's business processes (procurement, logistics, customer support, and so on), management innovation targets a company's management processes' (Hamel, 2006, p.76).

\section{The key characteristics of MI}

The definitions proposed earlier converge on four key aspects of MI: its multidimensional nature (it covers management practices but also structures, instruments, and processes), its novelty, which is accepted as relative, its intentionality (achieving organizational objectives, creating value) and its systemic nature (changing the organization overall). These characteristics are noted by Mol and Birkinshaw (2009), who also add the tacit nature of MI. They consider that MI must have all of the following four characteristics: (1) MI must involve a new conception of the firm, in its organization and its management, based on innovative concepts for known practices at a given point in time. An original management innovation is a significant advance in the "state of the art" regarding the firm's known management and organization practices. (2) MI must be implemented in practice inside the organization. It is 'tacit', i.e. it merges into routines to become an integral part of the corporate culture (Birkinshaw et al., 2008). (3) MI must bring concrete change to managers' ways of working in the firm. It can be recognized in innovative management practices that mark a break from the previous style of management or organization of relations in the firm. (4) MI must enhance the firm's performance.

In addition to these four characteristics, a fifth should be mentioned: the fact of becoming a standard that will gradually be adopted by the majority of firms (Mignon et al., 2017; Giuliani, Robert, 2017).

\section{A low consideration of openness in the MI research}


A recent systematic bibliometric review by Khosravi et al. (2019) - using a final sample of 66 empirical articles published between 1981 and 2017 underlines that the OI paradigm is notably absent from the theories most frequently mobilized to study MI, which relate more to resource-based and organizational learning theories. In regards to the MI antecedents, this research confirms finding made by other authors that among the four traditional groups of the antecedents (characteristics of the organization, managerial factors, environmental or external factors, and attributes of the innovation), internal factors (organizational and manager's characteristics) dominate, to the detriment of environmental ones (Mol, Birkinshaw, 2009; Damanpour Aravind, 2012; Volberda et al., 2013).

Organizational factors cover eight antecedents: organizational size, knowledge management, organizational structure and strategy, HR management, dynamic capabilities ${ }^{3}$, organizational culture, organizational resources and networks (Robert et al., 2017; Khallouk, Robert, 2018; Robert et al., 2019). The two most frequently-studied of these antecedents are organizational size and knowledge management, comprising acquisition, sharing, use and development of knowledge inside the firm. The level of analysis generally adopted in research on MI tends to be intra-organizational rather than inter-organizational.

Managerial factors include managers' characteristics and attitudes, stewardship, and leadership behaviours. Some researchers identify the impact on MI of managers' characteristics such as education, qualifications, and diversity (Damanpour, Schneider, 2006). Most of these studies have examined the influence of leadership styles (transformational and/or transactional) on MI, and found a positive association with MI (Vaccaro et al., 2012).

Environmental factors refer to the market or sector where the organization operates (Damanpour, Schneider, 2006; Ganter, Hecker, 2013). This category has three subcategories: market dynamics, political and legal aspects, and people/communities. They remain substantially less studied than internal antecedents. According to the review by Khosravi et al. (2019), the study by Damanpour and Schneider (2006) is the only one concerning the "community wealth" antecedent that could have a link with OI. Of the 10 environmental antecedents affecting MI, the most frequently-studied thus relate to competition in the markets, which seems to be a driver of greater adoption of MI with the goal of long-term performance.

We show in the following section that there is, however, other work that takes into account the "outside in" dimension of the IO and deals with aspects of integrating external knowledge, experience or external human resources (Birkinshaw et al., 2008; Mol, Birkinshaw, 2009, 2014; Huang, Rice, 2012; Dubouloz, Bocquet, 2013; Ganter, Hecker, 2013; Damanpour et al., 2018).

Regarding the effects of MI, OI is not identified as a potential consequence. However, some work highlights (product, process, marketing, social...) innovations as a possible consequence of management innovation (Azar, Ciabuschi, 2017; Nieves, 2016; Camison, Villar-Lopez, 2014; Pino et al., 2016, Mignon, et al., 2017; Giuliani et Robert, 2017; Le Roy et al., 2015). The literature describes this association as "synchronic" or "combinatory" (Damanpour et al., 2009; Mol and Birkinshaw, 2009). This approach assumes that management innovation and other categories of innovation combine in a virtuous circle to improve the company's performance. To achieve the best performance, it would be desirable to adopt a combination of different types of innovations. Nevertheless these studies do not suggest any link with OI paradigm.

\footnotetext{
${ }^{3}$ For example the study by Remon (2012) specifically dedicated to dynamic capabilities for open innovation.
} 


\section{OI AND MI: COULD THE LINKS BE CLOSER THAN THEY SEEM?}

It is clear from this review of the literature on MI and OI that these two fields have only very rarely been connected. However, the links between them may be less tenuous and fragmented than they appear at first sight. This section proposes a two-step analysis of this idea.

\section{OI: a relevant paradigm to explain the emergence and adoption of MI?}

As previously emphasized, the review of the literature about MI clearly shows a lack of reference to the OI paradigm in research on its antecedents and outcomes However, theoretical models of MI (Birkinshaw, Mol, 2008) and certain empirical findings suggest that the OI paradigm could be relevant to explain or foster emergence and adoption of MI (Mol, Birkinshaw, 2009, 2014 ; Huang, Rice, 2012; Dubouloz, Bocquet, 2013; Ganter, Hecker, 2013; Damanpour et al., 2018). We propose to identify here the elements in the MI literature suggesting the interest of the OI paradigm to study MI.

\section{The implicit reference to OI in some theoretical MI models}

From a theoretical standpoint, Armbruster et al. (2008) suggest that an MI can be understood as an intra-organizational or an inter-organizational innovation. In the second case, MI crosses the firm's boundaries and involves cooperations, alliances, networks and external actors. The same year, Birkinshaw and Mol (2008) propose an MI generation model that clearly brings out the roles and activities of agents for change, both internal and external, highlighting that openness remains essential to generate and implement MI. They also identify four distinct perspectives in the literature on MI: institutional, fashion, cultural and rational perspectives. The first two of these perspectives clearly refer to external actors' influences on the generation, adoption and diffusion of MI, notably through the work of Weitz and Shenhav (2000) and Abrahamson (1991). Volberda et al. (2014) identify four theoretical perspectives concerning research on MI: rational, institutional, 'international business', and 'theory development'. The role of external actors is broadly suggested by the last three perspectives, notably in the form of 'fashion-setters' in the institutional perspective, external capture and transfer of new tacit managerial practices via internal/external networks in multinational firms in the international business perspective, and finally academics in the theory development perspective.

Despite this explicit recognition of the role played by openness through diverse sources and external processes, few researchers have used these perspectives to empirically demonstrate the effect of openness on generation, adoption or diffusion of MI.

\section{Empirical results suggesting explicitly or not the relevance of the OI paradigm to study MI}

The relevance of the OI paradigm to explain MI has, however, been examined in few empirical studies without explicit reference to it (see table 1). First of all, using an empirical test based on data from British firms (CIS3), Mol and Birkinshaw (2009) show that knowledge from both the market (suppliers, customers, competitors, consultancies and external R\&D companies, universities, and public research institutions) and from other professional sources (conferences, scientific publications, and associations) is conducive to adoption of MI. Similarly, Ganter and Hecker (2013) replicated this study using German CIS data, and validated these initial findings. Although these two research do not explicitly refer to the OI paradigm, we can consider that the measure of search mobilized (sum of external 
markets and professional sources of knowledge) are like well-accepted measures of openness, such as the openness breadth suggested by Laursen and Salter (2006).

Then, besides these two empirical research, to our knowledge, only four studies have explicitly used the OI paradigm in the field of MI. They do not appear to have been identified for inclusion in the systematic bibliometric review by Khosravi et al. (2019) because they did not necessarily use the preselected key words, or were published in journals outside the scope of that review.

The first study used a sample of 4520 Australian firms. It shows that external sources of knowledge, and inter-organizational collaborations, are favourable for process innovation of both a technological and non-technological nature. MI belongs to this second category (Huang, Rice, 2012). The study also shows, however, that having too many external sources of knowledge can become counterproductive for MI. Eleven external sources of knowledge are identified in this study, grouped into three categories: market sources (clients, suppliers, consultants and competitors), institutional sources (universities, government agencies, private research institutions, and commercial laboratories) and professional sources. The degree of openness is once again calculated through the measure used by Laursen and Salter (2006) and ranges from 0 (no external sources of knowledge) to 11 (11 external sources of knowledge used by firms). Regarding inter-organizational collaborations, Huang and Rice (2012) aggregate six measures (joint marketing and distribution, joint manufacturing, joint $\mathrm{R} \& \mathrm{D}$, other joint ventures, licensing agreements, other forms of collaboration). In line with methods used in studies on OI, they add to these measures of openness firms' absorptive capacity (ACAP), measured through human capital in terms of skilled staff, graduates, and academic staff. In this approach, firms' ACAP is presumed to drive the search for new knowledge outside the firm, and combination of that knowledge with existing internal knowledge (Cohen, Levinthal, 1990).

The second study on a sample of 4319 French industrial firms also sets out to test the effect of firm openness on the intensity of MI adoption in terms of the number of new practices adopted (Dubouloz, Bocquet, 2013). The MI selected for this study is Lean Management and the openness is measured through the "breadth" variable proposed by Laursen and Salter (2006), which is the sum of five external sources: customers, private partners and suppliers connected to $\mathrm{R} \& \mathrm{D}$, public partners connected with $\mathrm{R} \& \mathrm{D}$, consultants, and external design advisors. This research also incorporates ACAP by using a measure that corresponds to its multidimensional nature and tests the combined effect of ACAP and openness on adoption of MI. It thus shows that having a variety of external sources of knowledge is favourable for adoption of MI up to a certain threshold, but beyond that point it has a negative effect. More surprisingly, the same study finds a substitution effect rather than a complementarity effect between ACAP and openness as regards MI.

Mol and Birkinshaw (2014) demonstrate the usefulness of an open innovation lens to the study of management innovation. They suggest that external involvement in the process of management innovating can transpire in three different ways: direct, input form external change agents; prior external experience of internal change agents; and the use of external knowledge sources by internal change agents.

The fourth study is more recent: Damanpour et al. (2018) use the OI paradigm in a study of US public administrations (a sample of 1512 public organizations), analysing the dual role of internal and external sources of knowledge on adoption of MIs that mainly come from the private sector. Their results show that the external involvement of service providers, consultants, service users, managers of other local government bodies, citizen advisory committees, and State agencies, as well as external implementation actions such as identifying successful uses of private alternatives or setting up citizen advisory committees, have a positive influence on MI adoption from the private sector. But they also highlight negative 
effects resulting from the combination of internal and external sources of knowledge even though individually they have direct positive effects.

Finally, our literature review shows that OI can be a relevant paradigm for studying antecedents to MI, since external sources of knowledge are drivers of MI. However, the combination of internal and external sources of knowledge merits further investigation in the future. We also note that the few studies linking OI and MI do so by focusing on the outsidein dimension of OI, referring only to the aspects of incorporation of knowledge, experience or external resources, or even inter-organizational collaborations. Table 1 gives an overview of the few empirical results that suggest the relevance of antecedents from the OI literature detailing their effects on MI, the methodologies used, if the corresponding research refer to outside-in inside-out or coupled OI process, and lastly if the reference to the OI paradigm is explicitly made or not.

Table 1 - Summary of empirical research on OI's effects on MI

\begin{tabular}{|c|c|c|c|c|c|}
\hline $\begin{array}{c}\text { ANTECEDENTS } \\
\text { RELATING TO OI }\end{array}$ & $\begin{array}{l}\text { TYPE OF } \\
\text { EFFECT }\end{array}$ & $\begin{array}{l}\text { METHOD- } \\
\text { LOGY }\end{array}$ & $\begin{array}{c}\text { OI } \\
\text { PROCESS }\end{array}$ & $\begin{array}{c}\text { EXPLICIT } \\
\text { REFERENCE } \\
\text { TO OI }\end{array}$ & REFERENCES \\
\hline \multirow{5}{*}{$\begin{array}{l}\text { External sources } \\
\text { of knowledge }\end{array}$} & \multirow{5}{*}{ Positive } & \multirow{5}{*}{ Quantitative } & \multirow{10}{*}{$\begin{array}{l}\text { OUTSIDE- } \\
\text { IN }\end{array}$} & $\begin{array}{l}\text { NO } \\
\text { YES }\end{array}$ & $\begin{array}{l}\text { Mol \& Birkinshaw (2009) } \\
\text { Mol \& Birkinshaw (2014) }\end{array}$ \\
\hline & & & & YES & Huang \& Rice (2012) \\
\hline & & & & YES & Dubouloz \& Bocquet (2013) \\
\hline & & & & NO & Ganter \& Hecker (2013) \\
\hline & & & & YES & $\begin{array}{l}\text { Damanpour, Sanchez- } \\
\text { Henriquez \& Chiu (2018) }\end{array}$ \\
\hline \multirow{2}{*}{$\begin{array}{l}\text { External sources } \\
\text { of knowledge }\end{array}$} & \multirow{2}{*}{$\begin{array}{l}\text { Negative } \\
\text { (Threshold } \\
\text { effect) }\end{array}$} & \multirow[b]{2}{*}{ Quantitative } & & YES & Huang \& Rice (2012) \\
\hline & & & & YES & Dubouloz \& Bocquet (2013) \\
\hline $\begin{array}{c}\text { Inter- } \\
\text { organisational } \\
\text { collaborations }\end{array}$ & Positive & Quantitative & & YES & Huang \& Rice, 2012 \\
\hline \multirow{2}{*}{$\begin{array}{l}\text { Combination of } \\
\text { openness and } \\
\text { ACAP }\end{array}$} & \multirow[b]{2}{*}{ Negative } & \multirow[b]{2}{*}{ Quantitative } & & YES & Dubouloz \& Bocquet (2013) \\
\hline & & & & YES & $\begin{array}{l}\text { Damanpour, Sanchez- } \\
\text { Henriquez \& Chiu (2018) }\end{array}$ \\
\hline
\end{tabular}

\section{MIs as vectors of OI: new structures and practices that serve openness}

As observed earlier (cf 1.1.2), recent research has called for a deeper understanding of the structures and practices associated with openness. Huizingh noted in 2010 that the question of 'how to do it' required new investigations, and recently West and Bogers (2016), Aloini et al. (2017), and Nisar et al. (2016) have shown that more attention should be paid to organizational forms that promote OI. Foss et al. (2011) also stressed the importance of appropriate organisation to encourage innovation with customers and users. One sign of growing interest, however, is the 2017 special issue of Business Process Management Journal entitled 'Implementing Open Innovation: technological, managerial and organizational tools', which contains an introduction by Aloini et al. that clearly stresses the importance of the organizational approach of openness. 
An analysis of the OI literature brings out the organizational changes required, leading to a closer link between the MI and OI literatures. It is an as yet emergent literature that recognizes that 'Organizations cannot implement open innovation without the right organizational structure' (Nisar et al., 2016, p. 5176). Nonetheless it belongs to a long tradition of structural innovation theories, presented explicitly by Gassman et al. $(2010)^{4}$ as the 'structural perspective' on OI. It mainly refers to the organizational and intraorganizationals level presented earlier by Bogers et al. (2018), incorporating organizational designs and practices. Two distinct groups of research can be identified, highlighting the organizational forms that should be considered in the openness process.

Table 2 - Organizational approach of OI: summary of research

\begin{tabular}{|c|c|c|c|}
\hline $\begin{array}{l}\text { TOPIC OF } \\
\text { THE } \\
\text { STUDY } \\
\end{array}$ & $\begin{array}{l}\text { METHOD- } \\
\text { OLOGY }\end{array}$ & ORGANIZATIONAL DIMENSIONS & REFERENCES \\
\hline \multirow{5}{*}{$\begin{array}{l}\text { Transition } \\
\text { from a } \\
\text { closed } \\
\text { model to } \\
\text { an open } \\
\text { model }\end{array}$} & \multirow[t]{5}{*}{$\begin{array}{l}\text { Qualitative } \\
\text { (case study) }\end{array}$} & $\begin{array}{l}\text { Networks of external actors, organisational structures } \\
\text { (dedicated units, champions or gatekeepers, incentive } \\
\text { systems), evaluation processes, knowledge } \\
\text { management system }\end{array}$ & Chiaroni et al. (2010) \\
\hline & & $\begin{array}{l}\text { Types of communication channels for knowledge } \\
\text { sharing, types of incentives, types of IPR }\end{array}$ & Felin \& Zenger (2014) \\
\hline & & $\begin{array}{l}\text { Culture, coordination of OI activities, momentum of } \\
\text { openness }\end{array}$ & $\begin{array}{l}\text { Mortara \& Minshall } \\
\text { (2011) }\end{array}$ \\
\hline & & Organizational support competency & $\begin{array}{l}\text { Appleyard \& } \\
\text { Chesbrough (2017) }\end{array}$ \\
\hline & & $\begin{array}{l}\text { Organizational learning, leadership, culture, processes } \\
\text { and instruments }\end{array}$ & Nisar et al. (2016) \\
\hline \multirow{8}{*}{$\begin{array}{l}\text { Open } \\
\text { model } \\
\text { (inside-out } \\
\text { and/or } \\
\text { outside-in) }\end{array}$} & \multirow[t]{8}{*}{ Quantitative } & Decentralized decision-making & Lee et al. (2019) \\
\hline & & Formalization and decentralization & Oltra et al. (2018) \\
\hline & & Decentralization and coordination of OI activities & Foss et al. (2013) \\
\hline & & $\begin{array}{l}\text { Organizational practices: intensive communication, } \\
\text { reward systems for employees sharing knowledge, } \\
\text { high levels of delegation of decision rights }\end{array}$ & Foss et al. (2011). \\
\hline & & $\begin{array}{l}\text { Organizational activities that promote employee } \\
\text { autonomy }\end{array}$ & Burcharth et al. (2017) \\
\hline & & Employees' individual characteristics & Bogers et al. (2018) \\
\hline & & Organizational culture & $\begin{array}{l}\text { Naqshbandi et al. } \\
\text { (2011) }\end{array}$ \\
\hline & & Knowledge Management oriented leadership & $\begin{array}{l}\text { Naqshbandi \& } \\
\text { Jasimuddin (2018) }\end{array}$ \\
\hline
\end{tabular}

The first group uses qualitative methodologies, and studies these forms by examining the transition from closed to open innovation. They thus focus on adoption of the open innovation model and the changes that entails. Appleyard and Chesbrouh (2017) insist on the importante of "organizational support competency" for openness. This competency requires a high commitment to Open Srategy and a conversion of organizational practices. Nisar et al. (2016) highlight five organizational factors to account for the move from a closed to an open model: organizational learning (approached through routines), leadership, culture, processes, and instruments. Chiaroni et al. (2010) emphasize four dimensions: inter-organizational networks (partners the firm works with for its development, particularly universities, research centres, users and suppliers), organizational structures (examined through the units dedicated to

\footnotetext{
${ }^{4}$ This study of the organization of innovations belongs to a long research tradition symbolized in the pioneering article by Sapolsky (1967).
} 
rolling out change, the presence of champions or gatekeepers, and incentive systems), evaluation processes (designating the mechanisms used to assess available external technologies and internal technologies to be promoted), and knowledge management systems (all the technological vectors used for diffusion and use of the systems, including IPR, which are presented as knowledge transfer mechanisms). The work of Mortara and Minshall (2011) shows the importance of culture (internal and external), coordination of OI activities (formal/informal - centralized/decentralized) and the momentum of openness (top-down or bottom-up). They describe four profiles of firms moving to an open mode of innovation including 'OI conscious adopters' that follow a top-down/centralized approach, and 'OI precursors' that take a more bottom-up/decentralized approach. Finally, Felin and Zenger (2014) refer to governance forms for $\mathrm{OI}^{5}$, approached through three dimensions: the types of communication channels for knowledge sharing, the types of incentives for openness, and the types of IPR for appropriating value from innovation.

The second group consists of research that does not focus on the shift from closed to open innovation, but on analysis of the organizational approach of either the inside-out or outsidein process, or both. These studies are quantitative in nature. Naqshbandi et al. (2011) show that organizational culture has a differentiated influence: it promotes outside-in processes but has no effect on inside-out processes. (Oltra et al. (2018) examine the role played by the organizational mechanisms of formalization and decentralization. Their results show that these two mechanisms have contrasting effects on inside-out processes: positive in the case of the former and negative in the case of the latter. Lee et al. (2019) assess the impact of decentralized decision-making on outside-in and inside-out processes. Naqshbandi and Jasimuddin (2018) study the type of leadership for knowledge management and its effect on outside-in and inside-out processes. This relates to the research by Foss et al. (2013), who underline the importance of organizational design in the possible exploitation of external resources and therefore new development opportunities ${ }^{6}$. Their study of 536 Danish firms brings out the positive role of decentralization and coordination. In another study of Danish firms, Foss et al. (2011) show how organizational practices play a key role in the specific case of user-centred innovation. They identify the following organizational practices: intensive vertical and lateral communication, rewarding employees for sharing and acquiring knowledge, and high levels of delegation of decision rights. In an outside-in perspective, they show how these organizational practices encourage the integration of knowledge derived from customers into innovation. Burcharth et al. (2017) examine organizational activities that foster employee autonomy, and their consequences for inbound and outbound innovation. More specifically, three activities are explored: supporting employees to work on their own idea, providing employees with time for creativity, and initiating 'intrapreneurial' activities. These activities are found to play a positive role for openness. In the same vein, Bogers et al .(2018) consider the 'human side of OI', highlighting the role employee characteristics play in firm openness. They show that knowledge diversity and educational diversity in the firm's employees have a positive influence on absorptive capacity.

The literature is thus paying increasing attention to the organizational approach of OI, starting by identifying dedicated designs and practices. It should be noted that while this emergent literature does not expressly mention the term MI, it does clearly show specific organizational

\footnotetext{
5 These governance forms are: for the closed model, hierarchy (based on authority or consensus), and for the open model, contractual relationships, alliances, platforms and user communities. Use of one of these governance forms is analysed through communication channels, incentive systems that encourage openness practices (knowledge sharing) involving financial or non-financial rewards, and the types of IPR (controlled by the local firm or subject to negotiation and exchanges).

${ }^{6}$ Although the authors do not speak explicitly of outside-in processes or OI.
} 
changes and forms for openness. This, in our view, indicates an important potential connection between MI and OI research, paving the way to research that explicitly incorporates a progressive approach to organizational designs and practices.

\section{MANAGEMENT INNOVATION AND OPEN INNOVATION: PROSPECTS FOR CROSS-FERTILIZATION}

Our detailed analysis of the literatures on OI and MI shows the value and relevance of taking a combined view for a finer-grained examination of their respective links, as the two bodies of literature echo each other without entering into explicit dialogue. Rather than being presented through a "mirror effect" as the literature proposes, they would both gain from and be mutually enriched by deliberate integration. The purpose of this final section is to suggest avenues for research that will advance that integration.

\section{Reference to the OI paradigm for research on external antecedents of MI}

From both a theoretical and empirical standpoint, the research has demonstrated the relevance of openness for MI. However, the studies concerned are very rare, and their findings remain fragmented and in need of further development.

The OI paradigm could be used for deeper examination of external antecedents of MI, which are currently underexplored in comparison to internal antecedents both structural and managerial (Damanpour, Aravind, 2012; Khosraviet al, 2018). It would also add depth to the initial results of research showing that external sources of knowledge are conducive to MI (Mol, Birkinshaw, 2009; Huang, Rice, 2012; Dubouloz, Bocquet, 2013; Ganter, Hecker, 2013; Damanpour et al., 2018), but only up to a certain threshold (Huang, Rice, 2012; Dubouloz, Bocquet, 2013). The exact threshold now needs to be defined more precisely, for example based on the firm's size, its intellectual capital, the type of external knowledge or external sources of knowledge, its ACAP, or even the type of MI process (generation, adoption and diffusion) or phases of those processes. Research using quantitative methodologies could validate and refine these initial results. Qualitative research, meanwhile, could offer processual approaches that can enhance understanding of the contributions and limitations of openness, in relation to the phases of adoption of a management innovation, for example.

Extant research that has implicitly or explicitly referred to OI in identifying external antecedents of MI has only applied qualitative methodologies, and only in relation to outsidein processes. New research could look at inside-out or coupled processes, and analyse the diffusion of MI through those processes. It would also be interesting to develop qualitative approaches for a deeper understanding of the human and inter-organizational mechanisms at play when the aim of openness is to generate and adopt MI. The geographical research settings should also be diversified in order to generalize and/or add nuance to the results in view of the national context (political system, population, market concentration). Comparisons conducted through studies of transnational samples should lead to identification of the respective roles played by local and national factors in MI.

Finally, different theoretical perspectives on MI could be used or integrated for a better understanding of the issues of openness regarding generation, adoption and diffusion of MI, in a variety of inter-organizational contexts. OI is often understood as a rational strategy used by firms to encourage innovation of any type (Chesbrough, 2006; Stanko et al, 2017). However, the motivations or reasons for openness could be less rational than they seem. There may be pressures and legitimacy-seeking behaviours at work, as well as strong influences from partners, researcher or the media. It would thus be interesting to analyse the OI-related 
antecedents of MI through the lens of different theoretical perspectives such as the institutional, fashion, international business, and theory development perspectives (Birkinshaw, Mol, 2008; Volberda et al., 2014), applying each one separately, and ideally integrating them into the same analytical framework. The effect of OI is conceivably variable, depending on the underlying reasons and motivations (rational, institutional, fad and fashion). Finally, over time the literature on OI has fine-tuned measures that can operationalize openness. The MI research using the OI paradigm, explicitly or otherwise, has generally only used the "search breadth" measure (Laursen, Salter, 2006). It would be interesting to see whether the depth of relations with external agents of change, the "search depth" (Laursen, Salter, 2006), can add nuance to the influence of openness on the chances of generating, adopting or diffusing a management innovation.

\section{Reference to the MI concept for research on the organisational dimension of OI}

As we have seen, a closer connection between the fields of MI and OI could also enhance understanding of OI processes that are not as automatic as is sometimes believed. This literature appears to suffer from an 'optimistic view' bias (Stanko et al, 2017), tending to underestimate the 'dark side' (Dalhander, Gann, 2010) of implementing openness. A few studies, however, explicitly identify obstacles to the OI process (Monteiro et al., 2017; Randhawa et al., 2018; Verbano et al., 2015) and in some cases show the necessity of paying particular attention to the organizational dimension of openness.

Research concerning organizational design and practices that can foster and facilitate OI or overcome the related obstacles would benefit from using the concept of MI and advances in research in that field. Several perspectives look very promising in this respect. A first area for research would concern the three recognized OI processes (outside-in or inbound, inside-out or outbound, and coupled), with the aim of identifying MIs that could facilitate them, or mitigate the obstacles noted in the literature (Van de Vrandeet al., 2009). The ability to incorporate external knowledge, or on the contrary to make use of (and perhaps a profit from) internal knowledge, or a combination of the two, require practical organizational arrangements and practices, with specificities that could be informed by the research on MI. A second area for research concerns the organizational practices, structures and processes that could be used for identification, assimilation and exploitation of external sources of knowledge, or in other words, management innovations that can improve organizations' ACAP, a factor often presented as an obstacle to OI (Lam et al., 2013). Few studies have focused on this phenomenon. However, the theoretical model developed by Lewin et al. (2011), which identifies a certain number of organizational routines comprising managerial programmes, procedures and practices, for example, deserve further study and empirical comparisons. It could thus be a springboard for research exploring new effects of MI.

Another question is whether MI could help firms to better exploit these external sources of knowledge, given that a threshold effect has been demonstrated that could perhaps be mitigated for small and medium-sized firms, for example (Lam et al., 2013). Research into this type of effect, and identification of MIs that could enhance the capabilities required for successful openness in innovation processes, are undeniably necessary at this stage. In short, MI research should explore new effects in addition to the effects on financial, operational and innovation performance. For example, structural and management innovations seem sorely necessary to coordinate, maintain and benefit from networks and external innovation communities. Two additional promising and necessary avenues of research could be identifying these MIs and analysing their effects on the durability and renewal of such collaborations, as well as their innovation performance. Finally, following on from Chiaroni et al., (2010), combining the contributions of the literatures on MI and OI in a longitudinal 
approach should help explain changes in organizational designs and practices through the different stages of a firm's transition from closed to open boundaries in order to innovate. The institutional and cultural perspectives on MI (Birkinshaw et al., 2008, Volberda et al., 2014) could be mobilized for this.

\section{Research into a potential 'Open Management innovation'}

Armbruster et al. (2008) are quick to suggest that a management innovation, whether a structure or a procedure, can be understood as an intra-organizational innovation, but also grasped from an inter-organizational angle. MIs can thus extend beyond the firm's boundaries and involve cooperations, alliances, networks and external actors; they may even represent a way of managing those cooperations, alliances, networks and external actors. Is an 'Open Management Innovation' thus conceivable? Could some OI-related instruments themselves, such as crowdsourcing (internal, external or mixed), be inter-organizational or open MIs?

Inter-organizational or open MIs could be studied as part of the dialogue between the OI and MI literatures which we argue in this paper is very relevant. There should be many benefits of connecting these two literatures to study 'Open Management innovation' mechanisms. Some authors have suggested that crowdsourcing for innovation is a management innovation as defined by Birkinshaw et al. (2008), but a management innovation that opens up more than the firm's boundaries (Chiu et al., 2014). In a similar vein, Di Gangi and Wasko (2009) examine the decision made by Dell to launch the IdeaStorm innovation crowdsourcing platform, bringing the platform launch process closer to organizational adoption of an MI. Crowdsourcing, a recognized OI instrument defined as 'a type of participative online activity in which an individual, an institution, a non-profit organization, or company proposes to a group of individuals of varying knowledge, heterogeneity, and number, via a flexible open call, the voluntary undertaking of a task' (Estellés-Arolas, González-Ladrón-de-Guevara, 2012, p. 197), could be such an 'Open Management innovation' mechanism. Although this mechanism is primarily conceived as chiefly targeting the external 'crowd', it has also been considered able to appeal for innovation to the internal 'crowd' of employees (Zuchowski, Posegga, Schlagwein \& Fischbach, 2016), in what the authors label 'internal crowdsourcing'. Other authors call the same concept 'participative innovation' or 'employee-driven innovation' (Kesting, Ulhoi, 2010). Recent experiments in France called Start Up de Territoire (Locally-rooted start-ups) have used Open Management innovation mechanisms to capture resources and ideas from people from all horizons, with different levels of expertise, to give rise to start-up projects oriented towards the Social and Inclusive Economy. An example of this type of 'face-to-face' crowdsourcing (people meeting physically in a chosen place for a few hours of creativity) was organized by the public body Pôle Sud Archer in Romans-sur-Isère in south-east France, an area that has been left marked by the decline of its local footwear industry during the 1980s/90s (Perret, Gagnon, 2016). This Open Management innovation approach triggered the formation of several start-up companies in an economically declining region. Beyond that area for exploration, a rich new field of research is opening up, explicitly blending the literatures on OI and MI.

\section{CONCLUSION}

This paper shows the full relevance of having a closer dialogue between the literatures on OI and MI than is currently the case. Some encouraging and extremely interesting results have 
been reported by MI research using the OI paradigm, and research on the organizational level of OI which echoes the MI literature. In particular, the literature on MI has examined the role of knowledge, experience and external agents in an outside-in perspective. The areas covered by MI research call for integration of the OI paradigm into the field of MI, to give 'Open Management innovation'. In parallel, the literature on OI has called for reflection on organizational design, structures, managerial practices in general and HR management in particular in order to manage openness. However, the links highlighted remain weak, and the number of studies is low. Also, the summary proposed here has shown their limitations and the need for replication or further investigation. Closer connections or a dialogue between the two fields of innovation management appears to be more than relevant and appropriate for their mutual enrichment. This study has identified promising and necessary research perspectives. More systematic discussions between these two communities could extend their respective boundaries and pave the way for a more integrative approach. This would give us an understanding of the conditions in which OI and MI respectively lead to other types of innovations, and what those types are, and in return how they feed and reinvent themselves in a recursive loop process. 


\section{REFERENCES}

ABRAHAMSON, E., (1991), Managerial Fads And Fashions: The Diffusion and Rejection of Innovations, Academy of Management Review, 16,586-612.

ALÄNGE, S., JACOBSON, S., JARNEHAMMAR, A., (1998), Some Aspects of An Analytical Framework For Studying The Diffusion Of Organizational Innovations. Technology Analysis \& Strategic management, 10(1), 3-19.

ALOINI, D., PELlEGRINI, L., LAZZAROTTI, V., MANZINI, R., (2017), Implementing Open Innovation: Technogical, Organizational And Managerial Tools, Business Process Management Journal. Special Issue, 23(6), 1083-1093.

ANTONS, D., PILLER, F. T. (2015). Opening The Black Box of "Not Invented Here": Attitudes, Decision Biases, and Behavioral Consequences. Academy of Management Perspectives, 29(2), 193217.

ARMBRUSTER, H., BIKFALVI, A., KINKEL, S., LAY, G. (2008), Organizational Innovation: The Challenge of Measuring Non-Technical Innovation in Large-Scale Surveys, Technovation, 28(10), 644-657.

AYERBE C., (2016), Rôles du brevet et articulation des connaissances : une analyse par la chaîne de valeur, Innovations, 1 (49), 79-102.

AYERBE, C., CHANAL, V., (2011), Quel management des DPI dans les business models ouverts?. Revue Française de Gestion, 99-115.

APPLEYARD, M. M., CHESBROUGH, H. W. (2017). The Dynamics of Open Strategy: From Adoption to Reversion. Long Range Planning, 50(3), 310-321.

AZAR, G., CIABUSCHI, F. (2017), Organizational Innovation, Technological Innovation, and Export Performance: The Effects of Innovation Radicalness and Extensiveness, International Business Review, 26(2), 324-336.

BATTISTI, G., STONEMAN, P. (2010), How Innovative Are UK Firms? Evidence from the Fourth UK Community Innovation Survey on Synergies Between Technological and Organizational Innovations, British Journal of Management, 2(1), 187-206.

BARBAROUX, P., ATTOUR, A. (2016), Approches interactives de l'innovation et gestion des connaissances, Innovations, 49(1), 5-14.

BIRKINSHAW, J.M., MOL, M.J. (2006), How Management Innovation Happens, MIT Sloan Management Review, 47(4), 81.

BIRKINSHAW, J., HAMEL, G., MOL, M. J. (2008), Management Innovation, Academy of Management Review, 33(4), 825-845.

BOCQUET, R., DUBOULOZ, S., CHAKOR, T. (2019), Lean Manufacturing, Human Resource Management and Worker Health: Are there Smart Bundles of Practices along the Adoption Process? Journal of Innovation Economics Management, (3), 113-144.

BOGERS, M., ZOBEL, A.-K., AFUAH, A., ALMIRALL, E., BRUNSWICKER, S., DAHLANDER, L., FREDERIKSEN, L., GAWER, A., GRUBER, M., HAEFLIGER, S., HAGEDOORN, J., HILGERS, D., LAURSEN, K., MAGNUSSON, M. G., MAJCHRZAK, A., MCCARTHY, I. P., MOESLEIN, K. M., NAMBISAN, S., PILLER, F. T., RADZIWON, A. (2017), The Open Innovation Research Landscape: Established Perspectives And Emerging Themes Across Different Levels Of Analysis, Industry \& Innovation, 24(1), 8-40.

BOGERS, M., FOSS, N.J., LYNGSIE, J., (2018), The "Human Side" Of Open Innovation: The Role Of Employee Diversity In Firm-Level Openness, Research Policy, 47, $218-231$.

BOLDRINI, J., SCHIEB-BIENFAIT, N. (2016), Comment initier une exploration collective ? Proposition d'un dispositif organisationnel, prélude aux partenariats d'exploration, Innovations, 49(1), 15-38.

BURCHARTH, A., PRÆST KNUDSEN, M.,SØNDERGAARD, H. (2017), "The role of employee autonomy for open innovation performance", Business Process Management Journal, 23 (6), 12451269. 
BÜSCHGENS, T., BAUSCH, A., BALKIN, D. B. (2013), Organizational culture and innovation: A meta-analytic review, Journal of Product Innovation Management,30(4), 763-781.

CAMISON, C., VILLAR-LOPEZ, A. (2014), Organizational innovation as an enabler of technological innovation capabilities and firm performance, Journal of Business Research, 67(1), 2891-2902.

CHESBROUGH H., (2003), Open Innovation - The New Imperative for Creating and Profiting from Technology, Harvard Business School Press.

CHESBROUGH H., (2006), Open Business Models, Harvard Business School Press

CHESBROUGH, H., BOGERS, M. (2014), Explicating Open Innovation: Clarifying an Emerging Paradigm for Understanding Innovation, in Chesbrough H.,Vanhaverbeke W., and West J., (eds), New Frontiers in Open Innovation, Oxford: Oxford University Press, 3-28

CHIARONI, D., CHIESA, V., FRATTINI, F., (2010), Unravelling The Process From Closed to Open Innovation: Evidence from Mature, Asset - Intensive Industries, $R \& D$ Management, 40(3), 222-245

CHIU, C.-M., LIANG, T.-P., TURBAN, E. (2014), What Can Crowdsourcing Do for Decision Support?, Decision Support Systems, 65, 40- 49.

COHEN, W., M., LEVINTHAL, D.A. (1990), Absorptive Capacity: A New Perspective on Learning and Innovation, Administrative Science Quarterly, 35, 128-152.

COHENDET, P., PÉNIN, J., (2011), Patents to Exclude Versus Include: Rethinking the Management of Intellectual Property Rights in a Knowledge-Based Economy, Technology Innovation Management Review, December, 12-17

DAHLANDER, L., GANN, D.M., (2010), How Open Is Innovation? Research Policy, 39 (6), 699709.

DAMANPOUR, F. (1991), Organizational Innovation: a Meta-Analysis of Effects of Determinants and Moderators, Academy of Management Journal, 34(3), 555-590.

DAMANPOUR, F. (2014), Footnotes to Research on Management Innovation, Organization Studies, 5(9), 1265-1285.

DAMANPOUR, F., ARAVIND, D. (2012), Managerial Innovation: Conceptions, Processes, and Antecedents, Management and Organization Review, 8(2), 423-454.

DAMANPOUR, F., EVAN, W. M. (1984), Organizational Innovation and Performance: The Problem Of Organizational Lag. Administrative Science Quarterly, 29, 392-409.

DAMANPOUR, F., SCHNEIDER, M. (2006), Phases of the Adoption Of Innovation Inorganizations: Effects Of Environment, Organization And Top Managers, British Journal of Management, 17(3), 215-236.

DAMANPOUR, F., WALKER, R. M., AVELLANEDA, C. N. (2009), Combinative Effects Ofinnovation Types And Organizational Performance: A Longitudinal Study Ofservice Organizations, Journal of Management Studies, 46(4), 650-675.

DAMANPOUR, F., SANCHEZ-HENRIQUEZ, F., CHIU, H. H. (2018), Internal And External Sources and the Adoption of Innovations in Organizations, British Journal of Management, 1-19.

DI GANGI, P. M., WASKO, M. (2009), Steal My Idea! Organizational Adoption of User Innovations from a User Innovation Community: A Case Study f Dell Ideastorm., Decision Support Systems, 48(1), 303- 312.

DUBOULOZ, S., BOCQUET, R. (2013), Innovation organisationnelle : S'ouvrir pour innover plus. Revue Française de Gestion, 39(235), 129-147.

EDQUIST, C., HOMMEN, C. L., MCKELVEY, M. (2001), Innovation and Employment: Process Versus Product Innovation. Cheltenham: Edward Elgar.

ENKEL, E., GASSMANN, O., CHESBROUGH, H., (2009), Open R\&D and Open Innovation: Exploring the Phenomenon, $R \& D$ Management, 39, 311-316.

ESTELLES-AROLAS, E., GONZALEZ-LADRON-DE-GUEVARA, F. (2012), Towards an Integrated Crowdsourcing Definition, Journal of Information Science, 38(2), 189- 200. 
FELIN T., ZENGER T.R., (2014), Closed or Open Innovation? Problem Solving and the Governance Choice. Research Policy, 43 (5), 914-925.

FLOR, M. L., COOPER, S. Y., OLTRA, M. J. (2018), External Knowledge Search, Absorptive Capacity and Radical Innovation in High-Technology Firms. European Management Journal, 36(2), 183-194.

FOSS, N. J., LAURSEN, K., PEDERSEN, T. (2011), Linking Customer Interaction and Innovation: The Mediating Role of New Organizational Practices, Organization Science, 22(4), 980-999.

FOSS, N., ZAHRA, S., LYNGSIE, J., (2013), The Role of External Knowledge Sources and Organizational Design in the Process of Opportunity Exploitation, Strategic Management Journal, 34(12), 1453-1471.

GANTER, A., HECKER, A. (2013), Deciphering Antecedents of Organizational Innovation, Journal of Business Research, 66(5), 575-584.

GASSMANN, O., ENKEL, E., (2004), Towards a Theory of Open Innovation: Three Core Process Archetypes, $R \& D$ Management Conference (RADMA), July 7-9, Lissabon.

GIULIANI, P., ROBERT, M. (2017), L'innovation managériale comme source d'innovations incrémentales de procédés, in Mignon, S., Chapellier, P., Mazars-Chapelon, P. \&Villesèque-Dubus,F. (eds),L'innovation managériale: Les multiples voies d'une spirale vertueuse, Caen, France, EMS Editions, 55-81.

GIULIANI, P., ROBERT, M., LE ROY, F. (2018), Reinvention of Management Innovation for Successful Implementation, International Journal of Entrepreneurship and Small Business, 343-361.

GOPALAKRISHNAN, S., BIERLY, P., KESSLER, E. H. (1999), A Reexamination of Product and Process Innovations Using a Knowledge-Based View, The Journal of High Technology Management Research, 10(1), 147-166.

HAMEL, G. (2006), The Why, What, and How of Management Innovation, Harvard Business Review, 84 (2), 72-84.

HAMEL, G., BREEN, B. (2008), The Future of Management, Harvard Business School Press, New York.

HENKEL, J. SCHÖBERL, S., ALEXY, O., (2014), The Emergence of Openness: How and Why Firms Adopt Selective Revealing In Open Innovation, Research Policy, 43, 879-890

HUANG, F., RICE, J. (2012), Openness in Product and Process Innovation, International Journal of Innovation Management, 16(4), 1-24.

HUIZINGH E.K.R.E, (2010), Open Innovation: State of Art and Future Perspectives, Technovation,31(1), 2-9.

KESTING, P., \& ULHØI, J. P. (2010), Employee-Driven Innovation: Extending the License to Foster Innovation, Management Decision, 48(1), 65-84.

KHALLOUK, M., ROBERT, M., (2018), Obstacles of Management Innovation in Nonprofit Organizations: The Case of an International Nongovernmental Organization. Innovations: Revue d'Economie et de Management de l'Innovation / Journal of Innovation Economics \&Management, 251, 183-210.

KHOSRAVI, P., NEWTON, C., REZVANI, A. (2019), Management Innovation: A Systematic Review and Meta-Analysis of Past Decades of Research, European Management Journal.

KIMBERLY, J. R. (1981). Managerial Innovation, In Nystrom P.C., Starbuck W. H., (eds), Handbook of organizational design, New-York: Oxford University Press, 84-104.

LAM, J. C. K., HILLS, P., NG, C. K. (2013), Open Innovation: A Study of Industry-University Collaboration in Environmental $\mathrm{R} \& \mathrm{D}$ in Hong Kong, International Journal of Technology, Knowledge and Society, 8(6), 83-102.

LAURSEN, K., SALTER, A. (2006), Open For Innovation: The Role of Openness in Explaining Innovation Performance Among U.K. Manufacturing Firms, Strategic Management Journal, 27(2), $131-150$ 
LEE, R., LEE, J. H., GARRETT, T. C. (2019), Synergy Effects of Innovation on Firm Performance, Journal of Business Research,99, 507-515

LE ROY, F., ROBERT, M., GIULIANI, P. (2015), Exploring the Link Between Technical and Management Innovation: The Moderating Effects of Firm Size and Type of Innovation, International Journal of Entrepreneurship and Small Business, 252, 171-191.

LEWIN, A. Y., MASSINI, S., PEETERS, C. (2011), Microfoundations of Internal and External Absorptive Capacity Routines, Organization science, 22(1), 81-98.

MIGNON, S., CHAPELLIER, P, MAZARS-CHAPELON, A., VILLESEQUE-DUBUS, F. (2017), L'innovation managériale : une spirale vertueuse, Editions EMS.

MIGNON, S., LAPERCHE, B. (2018), La connaissance: matrice de l'innovation ouverte, Innovations, 55(1), 5-12.

MOL, M.J., BIRKINSHAW, J. (2009), The Sources of Management Innovation: When Firms Introduce New Management Practices, Journal of Business Research, 62(12),1269-1280.

MOL, M.J., BIRKINSHAW, J. (2014), The Role of External Involvement in the Creation of Management Innovations, Organization Studies, 35 (9), 1288-1312.

MONTEIRO, F., MOL, M., BIRKINSHAW, J. (2017), Ready to Be Open? Explaining the Firm Level Barriers to Benefiting from Openness to External Knowledge, Long Range Planning, 2), 282295.

MORTARA, L., MINSHALL, T. (2011), How Do Large Multinational Companies Implement Open Innovation?, Technovation, 21, 586-597.

NAQSHBANDI, D. M., KAUR, S. (2011), Relative Capacity: Dimensions and Open Innovation. Journal of Management Research, 11(2), 77-86.

NAQSHBANDI, M.M., JASIMUDDIN, S.M., (2018), Knowledge-Oriented Leadership and Open Innovation: Role of Knowledge Management Capability in France-Based Multinationals, International Business Review, 27(3), 701-713.

NIEVES, J. (2016), Outcomes of Management Innovation: An Empirical Analysis in the Services Industry, European Management Review, 13(2), 125-136.

NISAR, A., PALACIOS, M., GRIJALVO, M., (2016), Open Organizational Structures: A New Framework for the Energy Industry, Journal of Business Research, 69 (11), 5175-5179.

PÉNIN, J., HUSSLER, C., BURGER-HELMCHEN, T. (2011), New Shapes and New Stakes: A Portrait of Open Innovation As a Promising Phenomenon, Journal of Innovation Economics \& Management, 7(1), 11-29.

PERRET, C., GAGNON, C. (2016), Le pôle territorial de coopération économique de Romans-surIsère dans la Drôme (France): une organisation au service de la relance de la dynamique territoriale. Revue Organisations \& Teritoires, 25(2), 29-36.

PINO, C., FELZENSZTEIN, C., ZWERG-VILlEGAS, A. M., ARIAS-BOLZMANN, L. (2016), Nontechnological Innovations: Market Performance of Exporting Firms in South America, Journal of Business Research, 69(10), 4385-4393.

PITSIS, T. S., SIMPSON, A., DEHLIN, E. (2012), Introduction: An Entrée to Organizational and Managerial Innovation. In Pitsis T., Simpson A., Dehlin E. (eds), Handbook of Organizational and Managerial Innovation, Edward Elgar Publishing, 1-9.

RANDHAWA, R., WILDEN, R., HOBERGER, J., (2016), A Bibliometric Review of Open Innovation: Setting a Research Agenda, The Journal of Product Innovation Management, 33(6), 750772.

RANDHAWA, K., WILDEN, R., GUDERGAN, S. (2018), Open Service Innovation: The Role of Intermediary Capabilities, Journal of Product Innovation Management, 35(5), 808-838.

REMON, D. (2012), Innovation ouverte et capacités dynamiques : préparation à la collaboration internationale des PME, Innovations, 2012/3,39, 71-98 
ROBERT, M., KHALLOUK, M., MIGNON, S. (2017), Les spécificités des organisations à but non lucratif sources d'innovations organisationnelles et managériales, Revue Française de Gestion, 43(264), 161-181.

ROBERT, M., GIULIANI, P., GUILLOTON, A., KHALLOUK, M. (2019), Management Innovation: A Dynamic Analysis of the Implementation Phase Over Time, Production Planning \& Control, 30(15), 1- 43.

STANKO, M. A., FISHER, G. J., BOGERS, M. (2017), Under the Wide Umbrella of Open Innovation. Journal of Product Innovation Management, 34(4), 543-558.

TROTT, P., HARTMANN, D., (2009), Why 'Open Innovation' Is Old Wine in New Bottles, Journal of Innovation Management, 13, 715-736.

VACCARO, I. G., JANSEN, J. J., VAN DEN BOSCH, F. A., VOLBERDA, H. W. (2012), Management Innovation and Leadership: The Moderating Role of Organizational Size, Journal of Management Studies, 49(1), 28-51.

VAN DE VRANDE, V., DE JONG, J. P., VANHAVERBEKE, W., DE ROCHEMONT, M. (2009), Open Innovation in Smes: Trends, Motives and Management Challenges, Technovation, 29(6-7), 423-437

VERBANO, C., CREMA, M., \& VENTURINI, K. (2015), The Identification and Characterization of Open Innovation Profiles in Italian Small and Medium-Sized Enterprises. Journal of Small Business Management, 53(4), 1052-1075.

VOLBERDA, H. W., VAN DEN BOSCH, F. A., HEIJ, C. V. (2013), Management Innovation:Management as Fertile Ground for Innovation. European Management Review,10(1), 115.

VOLBERDA, H. W., VAN DEN BOSCH, F. A., MIHALACHE, O. R. (2014), Advancing Management Innovation: Synthesizing Processes, Levels of Analysis, and Change Agents, Organization Studies, 35(9), 1245-1264.

WEITZ, E., SHENHAV, Y. (2000), A Longitudinal Analysis of Technical and Organizational Uncertainty in Management Theory, Organization Studies, 21, 243-266.

WEST, J., VANHAVERBEKE, W., CHESBROUGH, H. (2006), Open innovation: A Research Agenda. In Open Innovation: Researching a New Paradigm, (eds) Chesbrough, H. Vanhaverbeke W., and West J., Oxford: Oxford University Press, 285-307.

WEST, J., BOGERS, M., (2014), Leveraging External Sources of Innovation: A Review of Research on Open Innovation, Social Science Electronic Publishing, 31, 814-831.

WEST, J., SALTER, A., VANHAVERBEKE, W., CHESBROUGH, H., (2014), Open Innovation: The Next Decade, Research Policy. 43, 805-811.

WEST, J., SALTER, A., VANHAVERBEKE, W., CHESBROUGH, H., (2006), Open Innovation: A Research Agenda. In Open Innovation Researching a New Paradgim. (eds), Chesbrough H., Vanhaverbeke W., and West J. Oxford: Oxford University Press, 285-307.

ZUCHOWSKI, O., POSEGGA, O., SCHLAGWEIN, D., FISCHBACH, K. (2016), Internal Crowdsourcing: Conceptual Framework, Structured Review, and Research Agenda, Journal of Information Technology, 31(2), 166-184. 